\title{
Does the Cannulated Screw Tension Band Improve Quadriceps Muscle Strength, Atrophy, Implant Irritation and Functional Results in Patella Fractures Compared to the Kirschner Wire Tension Band?
}

\author{
Kanüllü Vida Gergi Bandı, Kirschner Teli Gergi Bandına Göre Patella Kırıklarında \\ Kuadriseps Kas Gücünü,Atrofiyi, İmplant İritasyonunu ve Fonksiyonel Sonuçları \\ İyileştirir Mi?
}

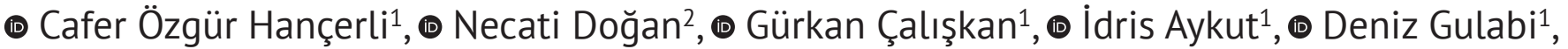 (1) Cemil Ertürk ${ }^{1}$

${ }^{1}$ University of Health Sciences Turkey, Kanuni Sultan Süleyman Training and Research Hospital, Clinic of Orthopaedics and Traumatology, Istanbul, Turkey

${ }^{2}$ University of Health Sciences Turkey, İstanbul Başakşehir Çam and Sakura City Hospital, Clinic of Orthopaedics and Traumatology, Istanbul, Turkey

Background: We aimed to evaluate the effects of the cannulated screw tension band and Kirschner $(\mathrm{K})$ wire tension band methods on quadriceps muscle strength and atrophy, implant irritation and functional results in the treatment of patella fractures.

Materials and Methods: In this study, 70 patients with a diagnosis of patella fracture, who were operated in our clinic between January 2015 and May 2019, were retrospectively evaluated. Patients were operated in two separate groups: in group 1, 21 patients were fitted with a cannulated screw tension band, and in group 2,49 patients were treated by the $\mathrm{K}$ wire tension band method. The Lysholm score was used for clinical evaluation. The loss of extensor muscle strength in the patients was measured with an analogue dynamometer.

Results: There was no difference in the effect of two different techniques, age, gender, and fracture type on the duration of fracture union in the surgical treatment of patella fractures $(p>0.05)$. Clinically, there was no difference in Lysholm score between the two groups ( $p>0.05$ ). Knee extensor muscle strength decreased in both groups compared to the healthy side ( $p<0.05)$, and the two groups were similar $(p>0.05)$. We found that the thigh diameter was decreased compared to the healthy side in patients who underwent surgery for patella fracture $(p=0.001)$. There was no difference in thigh diameter difference between the two groups ( $p>0.05$ ).

Conclusion: With the two different techniques, quadriceps muscle strength, atrophy and clinical results were similar. In the K-wire tension band method, more implant removal was required due to irritation.

Keywords: Cannulated screw tension band, Kirschner wire tension band, muscle strength loss, patella fracture

Amaç: Patella kırıklarının tedavisinde kanüllü vida gergi bandı ve Kirschner (K) teli gergi bandı yöntemlerinin kuadriseps kas gücü ve atrofisi, implant iritasyonu ve fonksiyonel sonuçlar üzerindeki etkilerini değerlendirmeyi amaçladık.

Gereç ve Yöntemler: Bu çalışmada Ocak 2015-Mayıs 2019 tarihleri arasında kliniğimizde patella kırığı tanısı alan 70 hasta retrospektif olarak değerlendirildi. Hastalar iki ayrı grupta ameliyat edildi: Grup 1'de 21 hastaya kanüllü vida gergi bandı uygulandı ve grup 2'de 49 hasta K tel gergi bandı yöntemi ile tedavi edildi. Lysholm skoru klinik değerlendirme için kullanıldı. Hastalarda ekstansör kas gücü kaybı analog dinamometre ile ölçüldü.

Bulgular: Patella kırıklarının cerrahi tedavisinde iki farklı tekniğin,yaş, cinsiyet ve kırık tipinin kırığın kaynama süresi üzerine etkisinde fark yoktu ( $p>0,05)$. Klinik olarak Lysholm skorunda iki grup arasında fark yoktu $(p>0,05)$. Her iki grupta diz ekstansör kas gücü sağlıklı tarafa göre azaldı $(p<0,05)$ ve iki grup benzerdi $(p>0,05)$. Patella kırığı nedeniyle ameliyat edilen hastalarda uyluk çapının sağlıklı tarafa göre azaldığını saptadık ( $p=0,001)$. İki grup arasında uyluk çapı açısından fark yoktu ( $p>0,05)$.

Address for Correspondence: Cafer Özgür Hançerli, University of Health Sciences Turkey, Kanuni Sultan Süleyman Training and Research Hospital, Clinic of Orthopaedics and Traumatology, İstanbul, Turkey

Phone: +905335773159 E-mail: cozgurhancerli@yahoo.com.tr ORCID ID: orcid.org/0000-0002-4518-1998

Received: 10.03.2021 Accepted: 12.07.2021 
Sonuç: Kuadriseps kas gücü, atrofi ve klinik sonuçlar iki farklı teknikle benzerdi. K-teli gergi bandı yönteminde tahriş nedeniyle daha fazla implant çıkarılması gerekiyordu.

Anahtar Kelimeler: Kanüllü vida gergi band, Kirschner tel gergi bandı, kas gücü kaybı, patella kırığı

\section{Introduction}

Patella fractures are among the fractures, whose frequency is increasing with the increase of traffic accidents and occupational accidents, and they constitute approximately $1 \%$ of all fractures (1). The main task of the patella is to contribute to knee extension by increasing the strength of the quadriceps muscle (2). The most common type of fracture is a transverse fracture, which is indirectly traumatic. The accepted indications for surgery are the absence of active knee extension and more than $2 \mathrm{~mm}$ of displacement between the parts and stepping inside the joint $(1,3)$. Inadequate treatment after patella fractures leads to decreased knee extension strength, loss of range of motion in the knee joint, and patellafemoral and tibia femoral arthritis (4).

Different methods used in the surgical treatment of patella fractures continue to be interesting (5). Many methods have been defined in the treatment, and predictable union rates have been achieved with these treatment methods. The most classical method in treatment is the tension band method, which is applied together with Kirschner $(K)$ wires, which converts the tensile forces into compression forces in the fracture line (6). Although tension band with K-wires is the most commonly used method in the surgical treatment of patella fractures, problems such as implant irritation $(7,8)$, loss of quadriceps muscle strength $(7,8,9)$ and quadriceps atrophy (10) have been reported to occur due to K-wires. Therefore, a solution was sought with tension bands passing through the cannulated screw as an alternative to the tension band made with K-wires $(9,11)$.

Current studies show that there is less skin and quadriceps muscle trauma with tension bands passing through the cannulated screw (12). On the other hand, studies comparing these two methods in terms of quadriceps muscle weakness, quadriceps atrophy and clinical results are quite limited (13). For this reason, in this study, we wanted to retrospectively compare the results of cases with the cannulated screw tension band method and the K-wire tension band method.

\section{Material and Methods}

Patients admitted to our hospital with a diagnosis of displaced patella fracture between January 2015 and May 2019 were evaluated retrospectively. Approval for this study was obtained from the University of Health Sciences Turkey, Kanuni Sultan Süleyman Training and Research Hospital,
Ethics Committee for this study (KAEK/2018.12.78). Exclusion criteria were as follows: patients whose records could not be accessed, those with a history of septic arthritis, osteomyelitis or poliomyelitis in their lower extremities, or a history of concurrent or previous lower extremity fractures, patients who had undergone more than one operation, who did not accept surgical treatment or who were operated in another hospital, patients who did not accept surgery and patients who had fracture type AO, type A or type B, old fractures, and open or pathological fractures.

Of the 70 patients included in the study, 21 patients (group 1) were treated by applying an anterior 8-shaped tension band $(9,12)$ with self-compressing fully threaded headless screws and cerclage wires passing through screw holes (Figure 1 a, b, c, d), and 49 patients (group 2) were treated with 2 K-wires $(5,6)$ and the 8-shaped anterior

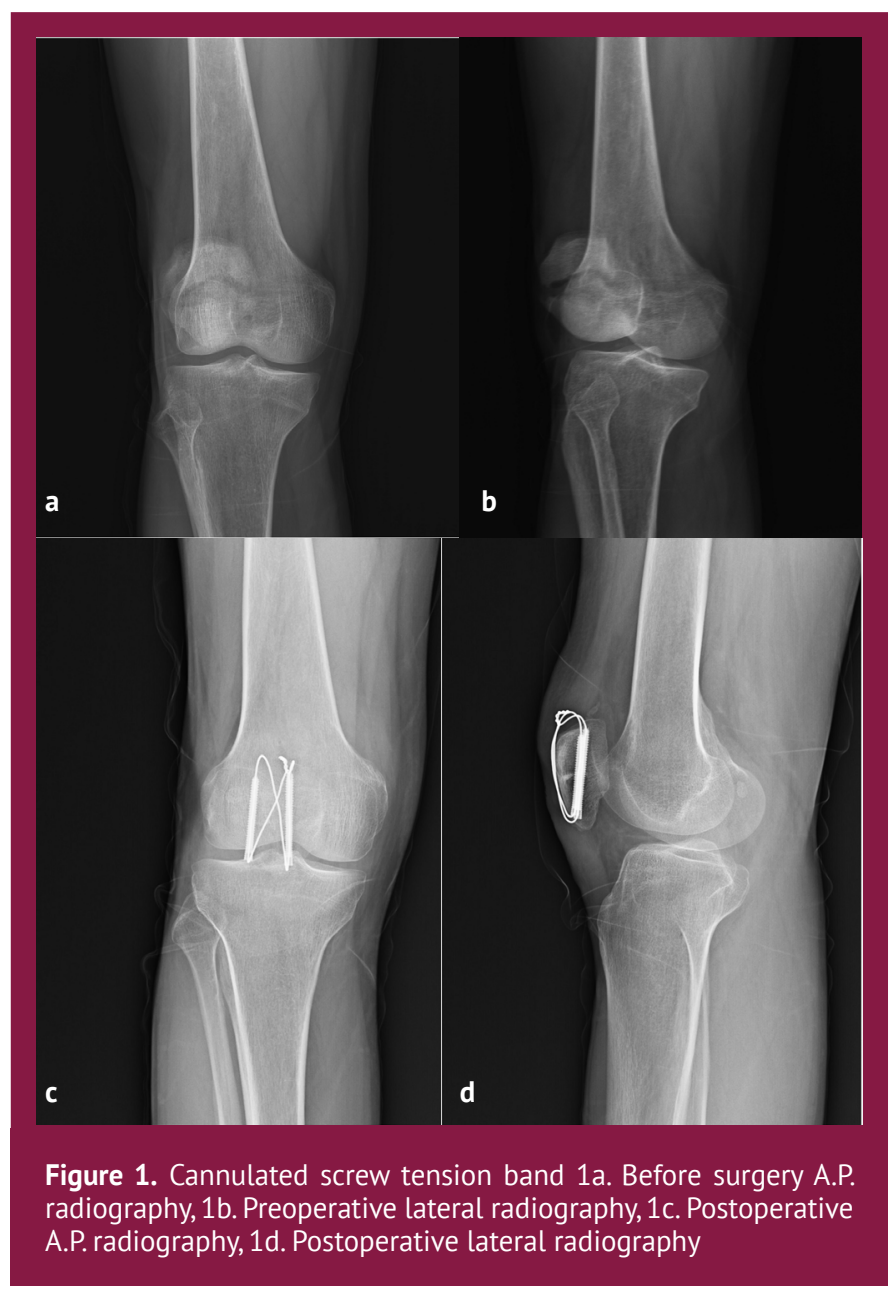


tension band method $(5,6)$ applied around the K-wires (Figure 2 a, b, c, d).

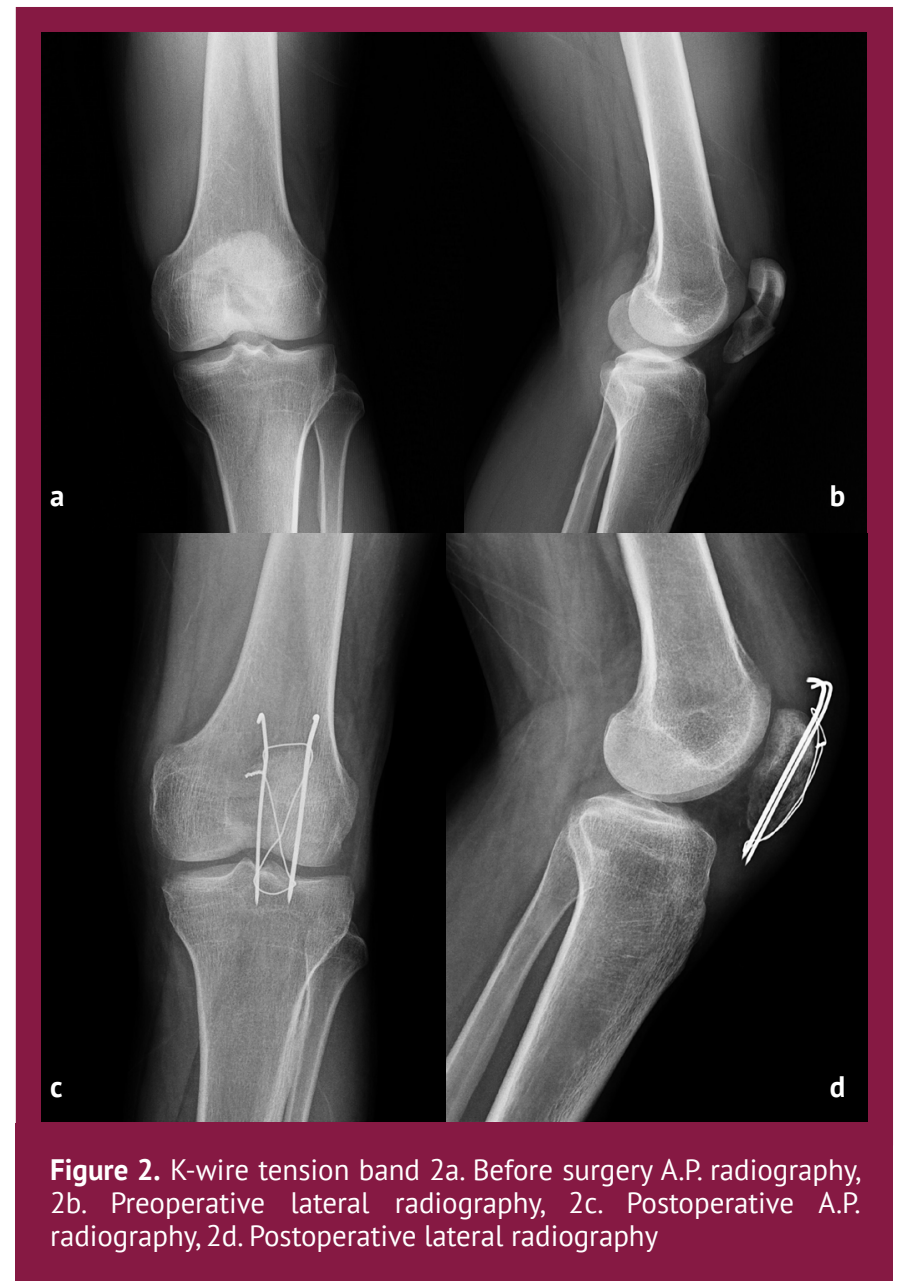

A long leg plaster splint was applied to the patients in both groups after surgery for approximately two weeks. In the second week, the splints were removed, joint movements were initiated by allowing 90 degrees of flexion with the angle-adjusted knee brace. Physical therapy was applied to the patients in various centers in the sixth postoperative week.

At the final check, the range of motion of the joint and the intact side and the operated side thigh diameters of all patients were measured in the standing and lying positions from the mid-thigh, and quadriceps muscle strength was measured on both sides (13). Quadriceps muscle strength was measured by a specialist physiotherapist using an analogue dynamometer, by asking the patients to perform forced extension while the knee was flexed at 90 degrees. Before the measurement, the patients were given warm-up exercises for 10 minutes and the measurement was explained. Three separate measurements were made to both lower extremities and the average of these measurements was taken. The difference of quadriceps strength on the operated side compared to the healthy side was expressed as percentage decrease by calculating with the formula (healthy side muscle strength - operated side muscle strength)/healthy side muscle strength. Patients with implant irritation were removed, and their final control was clinically evaluated after removal.

Short form-36 (SF-36), Knee Injury and Osteoarthritis Outcome score (KOOS) and Lysholm scoring systems are frequently used to determine the health status of patients with patella fractures (5). With the SF-36, results are affected by environmental factors, as it evaluates the physical function of the patient as well as the emotional state and social functions. KOOS, on the other hand, is a test for knee osteoarthritis. This is why we chose to use the Lysholm test, which only includes questions about knee problem (11). The Lysholm knee score is a knee scoring scale that asks whether patients have disruption while walking, whether they use support, whether there is a locking in the knee, knee joint stability, the character of the knee pain, swelling, and whether they have problems while climbing stairs or crouching.

The most reliable method for measuring muscle strength is the biodex dynamometer (14). However, measuring muscle strength with this method is expensive and requires special training,whereas measurement of quadriceps muscle strength with an analogue dynamometer is an easy and inexpensive method. The reliability of this method was shown in the study (14). Measurements made with an analogue dynamometer are generally used after knee ligament injuries and the reconstruction of these injuries. The disadvantage of the method is the difficulty of patient compliance. We also used an analogue dynamometer to measure quadriceps muscle strength in our patients.

\section{Statistical Analysis}

Statistical Package for the Social Sciences 22 was used for statistical analysis. The data obtained by counting were expressed as a percentage and the data obtained by measurement as a ratio and mean \pm standard deviation. Evaluation of whether the data obtained from the measurements were suitable for normal distribution was performed with the Kolmogorow-Smirnov test. The t-test or Mann-Whitney $U$ test was used for the comparison of groups. Categorical data were analyzed using the chi-square tests. A p value of less than 0.05 was considered statistically significant.

\section{Results}

The demographic data of the patients are shown in Table 1. The two groups were similar in terms of gender, age, side, type of fracture and duration of union ( $p>0.05$ ). 


\begin{tabular}{|l|l|l|l|}
\hline \multicolumn{4}{|l|}{ Table 1. Demographic data of the patients } \\
\hline & $\begin{array}{l}\text { Grup I } \\
(\mathbf{n = 2 1 )}\end{array}$ & $\begin{array}{l}\text { Grup II } \\
\text { (n=49) }\end{array}$ & $\mathbf{p}$ \\
\hline Gender (male/female) & $15 / 6$ & $40 / 9$ & $\mathbf{0 . 0 8}$ \\
\hline Fracture side (right/left) & $4 / 17$ & $18 / 31$ & 0.577 \\
\hline Age & 41.3 & 39.3 & 0.302 \\
\hline Dominant side (right/left) & $17 / 4$ & $41 / 8$ & 0.593 \\
\hline Fracture type (C1/C2/C3) & $10 / 7 / 4$ & $30 / 13 / 6$ & $\mathbf{0 . 3 9 9}$ \\
\hline Fracture union(day) & 51.7 & 58.5 & 0.950 \\
\hline Follow-up time (month) & 35.7 & 29.9 & $\mathbf{0 . 4 5 1}$ \\
\hline
\end{tabular}

When a comparison was made with the healthy side in the quadriceps muscle strength measurement performed with an analogue dynamometer, there was a $33.5 \%$ decrease in group 1 and a $34.4 \%$ decrease in group 2 . The difference was significant in terms of reduction in muscle strength $(p<0.05)$. When all patients were evaluated, a $34.1 \pm 21.9 \%(0$ $80)$ loss of strength on the fracture side was found. There was no significant difference in muscle strength loss in patients with screws and K-wires ( $p>0.05)$. There was an average of $1.5 \mathrm{~cm}$ (group 1: $1.66 \mathrm{~cm}$, group 2: $1.44 \mathrm{~cm}$ ) difference in thigh diameter in the operated patients, but there was no significant difference between the two groups $(p>0.05)$. Implants had to be removed in 22 patients due to irritation. The implants of one (4.7\%) patient in group 1 and 21 (42.8\%) patients in group 2 were removed. There was a significant difference between the two groups $(p<0.001)$. Implant removal procedures were performed after an average of 9.2 months (3-21 months). There was no statistically significant difference in the measurement of quadriceps muscle strength in group 2 patients with implants compared to patients without implants $(p<0.05)$ Table 2.

The Lysholm knee score was $89.95 \pm 4.4$ (81-99) in group 1 and $91.1 \pm 6.6$ (78-100) in group 2. There was no significant difference between the groups ( $p>0.05)$.

The range of motion of the joint was evaluated as "complete" in all patients, except for a limitation of 30 degrees of flexion in one patient to whom a tension band was applied. No implant-related infection was encountered in the patients. Heterotopic ossification (two patients in the lower pole of the patella and one patient in the upper pole) was detected in the last follow-up of three of our patients.

Table 2. Clinical results of both techniques

\begin{tabular}{|l|l|l|l|}
\hline & $\begin{array}{l}\text { Grup I } \\
(\mathbf{n = 2 1 )}\end{array}$ & $\begin{array}{l}\text { Grup II } \\
(\mathbf{n = 4 9 )}\end{array}$ & $\mathbf{p}$ \\
\hline Loss of muscle strength (\%) & 33.5 & 34.4 & $\mathbf{0 . 9 4 4}$ \\
\hline The decrease in thigh diameter (cm) & 1.66 & 1.44 & 0.631 \\
\hline Lysholm score & 89.95 & 91.1 & 0.617 \\
\hline Implant removal & 1 & 21 & 0.001 \\
\hline
\end{tabular}

\section{Discussion}

The main results of this study were, first, that there was no difference between the two groups in terms of quadriceps muscle strength and thigh diameter, but in both groups, the operated side quadriceps strength and thigh diameter were significantly weakened compared to the non-operated side. Second, implant irritation was more in the tension band with $\mathrm{K}$-wire. Therefore, the need for implant removal was greater with the tension band with K-wire. Third, both groups were similar in clinical and radiological healing. Finally, the tension band with K-wire was similar in quadriceps muscle strength in the subgroups with and without implants.

Many treatment methods are used in the surgical treatment of patella fractures. Although the K-wire tension band is the preferred method, methods such as cannula screw, arthroscopy-assisted cannula screw, cannula screw tension band, screw-plate and non-absorbable suture osteosynthesis are used. Partial or total patellectomy can be applied in fractures where fixation is not possible. However, the search for the best treatment method continues. The most important reason for the search for treatment methods is that the K-wire tension band causes implant irritation. The cannula screw and tension band method, on the other hand, has become a preferred method with less implant irritation and less need for implant removal. K-wire tension band and/or circumferential sutures continue to be the current treatment method for multi-part fractures and fractures where the broken pieces are too small to apply screws (AO C3-1, C3-2, C3-3).

A decrease in extensor muscle strength after patella fracture is a frequently encountered situation (13). This decrease in extensor muscle strength may be the inevitable consequence of an injured extensor mechanism. However, patients' avoidance of the injured extremity may also be the cause of weakness. In the measurements we made, we found that approximately $80 \%$ of the patients had a decrease in muscle strength. Results of extensor muscle strength measurement with an analogue dynamometer, which we applied an average of 31.6 months after surgery, were significantly lower, regardless of the complaints of the patients $(13,15)$. Quadriceps atrophy is a common condition after patella fracture (10). The decrease in thigh diameter on the operated side was significant in the measurements we made in the patients, but the decrease in thigh diameter was not different between the two groups.

Although the search for the best surgical method to be applied in patella fractures continues, the K-wire tension band method is the most common method (16). The most common complication of K-wire tension band application is anterior knee pain due to implant irritation. Although symptomatic 
implant removal is not seen as a serious complication, it causes an unplanned second operation and increases costs (12). In the literature, the proportion of patients requiring implant removal due to anterior knee pain is around $36.8 \%$. In our series, this rate was $42.8 \%$. In addition, the absence of a significant difference in the decrease in quadriceps muscle strength of patients with and without implants, in patients to whom we applied a tension band with K-wires, suggests that the loss of muscle strength may be associated with the injury to the extensor mechanism due to trauma rather than the method used (13).

Common complications after patella fracture surgery are implant irritation, joint stiffness, loss of reduction, osteoarthrosis, infection, and non-union. Joint stiffness is the most common complication in patella fractures, regardless of the treatment method. Immobilization lasting longer than six weeks results in joint stiffness (17). In our patients, there was no difference between the two methods in terms of joint stiffness. It has been reported that $0-20 \%$ loss of fixation occurs in patella fractures treated with surgery $(17,18)$. In our series, a patient in whom we applied a tension band $\mathrm{K}$-wire developed fixation loss in the first month, and then revision was performed with the screw tension band method. Osteoarthrosis may occur as a result of joint damage at the time of injury. It has been shown radiographically that there is a greater incidence of patellofemoral arthrosis when compared to the contralateral extremity years after fracture healing (19). In our cases, patellofemoral osteoarthrosis was present in three of our patients to whom K-wire tension bands were applied. The reason for the low rate of osteoarthrosis may be the short follow-up period. Infection can be seen in $3-30 \%$ of patellar fractures treated with surgery $(17,18)$. In our series, we did not have any patients who developed infection. Nonunion after surgical treatment of patella fractures is a rare complication. In our series, all patients had adequate union. In a meta-analysis report, it was emphasized that there was no difference in the surgical success rate, operation time, fracture healing time, and the number of infections between cannulated screw and K-wire tension tape in the treatment of patellar fracture, but cannulated screw tension tape was superior to $\mathrm{K}$ wire tension tape in reducing the incidence of complications (5).

In recent years, many biomechanical studies have been performed in the treatment of patellar fractures, both in cadavers and in artificial bone models $(20,21,22)$. In these studies, the cannulated screw tension band method has been accepted as the most powerful biomechanical fixation method (23). Since these studies were carried out under laboratory conditions, their effects on fracture healing are controversial. On the other hand, similar results have been reported in terms of clinical results related to both methods (12). The results were similar in the Lysholm knee scoring of group 1 and group 2 patients at the final check. This finding is compatible with the literature (5). On the other hand, although fewer patients were treated with the cannulated screw in our study than with K-wire, the union times were similar. Likewise, we obtained clinically similar results in both groups (12).

\section{Study Limitations}

This study had some limitations. First, it was a singlecenter and retrospective study. Second, the patient group in which the cannulated screw tension band was applied was significantly smaller than the patient group in which the K-wire tension band was applied.

In this study, a comparison was made between the cannulated screw and K-wire tension band methods in patellar fractures regarding clinical and radiological improvement and quadriceps muscle strength. Although a greater need for implant removal was determined in the K-wire tension band method due to irritation, quadriceps muscle strength and atrophy were similar in the subgroups with and without implants, although they were weaker compared to the healthy leg.

\section{Conclusion}

We think that it would be more meaningful to focus on physical therapy protocols to increase muscle strength after treatment in patella fractures rather than on the choice of treatment method.

\section{Ethics}

Ethics Committee Approval: Approval was obtained from the University of Health Sciences Turkey, Kanuni Sultan Süleyman Training and Research Hospital, Ethics Committee for this study (KAEK/2018.12.78).

Informed Consent: Patients admitted to our hospital with a diagnosis of displaced patella fracture between January 2015 and May 2019 were evaluated retrospectively.

Peer-review: Externally and internally peer-reviewed.

\section{Authorship Contributions}

Surgical and Medical Practices: C.Ö.H., N.D., G.Ç., D.G., C.E., Concept: C.Ö.H., N.D., C.E., Design: C.Ö.H., N.D., G.Ç., I.A., D.G., C.E., Data Collection or Processing: C.Ö.H., N.D., G.Ç., D.G., C.E., Analysis or Interpretation: C.Ö.H., N.D., Literature Search: C.Ö.H., N.D., C.E., Writing: C.Ö.H., N.D., G.Ç., I.A., D.G., C.E.

Conflict of Interest: No conflict of interest was declared by the authors.

Financial Disclosure: The authors declared that this study received no financial support. 


\section{References}

1. Boström A. Fracture of the patella. A study of 422 patellar fractures. Acta Orthop Scand Suppl. 1972;143:1-80. [Crossref]

2. Muralidhar BM, Madhusudan H, Mohan M. Study of patellar fractures treated by modified tension band wiring-a prospective study. Int I Orthop Sci. 2017;3:864-871. [Crossref]

3. Melvin JS, Mehta S. Patellar fractures in adults. J Am Acad Orthop Surg. 2011;19:198-207. [Crossref]

4. Vedel JO, Vistrup S, Larsen P, Elsoe R. Altered long-term health-related quality of life in patients following patella fractures: a long-term followup study of 49 patients. Eur J Trauma Emerg Surg. 2018;44:707-716. [Crossref]

5. Zhang Y, Xu Z, Zhong W, Liu F, Tang J. Efficacy of K-wire tension band fixation compared with other alternatives for patella fractures: a metaanalysis.J Orthop Surg Res. 2018;13:226. [Crossref]

6. Blum L, Hake M. Orif patella fracture with a tension band construct. Orthop Trauma. 2017;31(Suppl 3):S8-S9. [Crossref]

7. Tian Y, Zhou F, Ji H, Zhang Z, Guo Y. Cannulated screw and cable are superior to modified tension band in the treatment of transverse patella fractures. Clin Orthop Relat Res. 2011;469:3429-3435. [Crossref]

8. Kim MB, Lee YH, Shin WC, Baek GH. Locked tension band wiring using ring pins for patellar fractures: a method of minimising implant migration. Arch Orthop Trauma Surg. 2014;134:1537-1543. [Crossref]

9. Malik M, Halwai MA. Open reduction and internal fixation of patellar fractures with tension band wiring through cannulated screws. J Knee Surg. 2014;27:377-382. [Crossref]

10. Vatansever M, Kuyurtay F, Sadioğlu M. Surgical management of patellar fractures. Acta Orthop Traumatol Turc. 1996;30:290-293. [Crossref]

11. Lin T, Liu J,Xiao B, Fu D, Yang S. Comparison of the outcomes of cannulated screws vs. modified tension band wiring fixation techniques in the management of mildly displaced patellar fractures. BMC Musculoskelet Disord. 2015;16:282. [Crossref]

12. Hoshino CM, Tran W, Tiberi JV, Black MH, Li BH, Gold SM, et al. Complications following tension-band fixation of patellar fractures with cannulated screws compared with Kirschner wires.J Bone Joint Surg Am. 2013;95:653659. [Crossref]

13. LeBrun $\mathrm{CT}$, Langford JR, Sagi HC. Functional outcomes after operatively treated patella fractures.J Orthop Trauma. 2012;26:422-426. [Crossref]

14. Almeida GPL, Albano TR, Melo AKP. Hand-held dynamometer identifies asymmetries in torque of the quadriceps muscle after anterior cruciate ligament reconstruction. Knee Surg Sports Traumatol Arthrosc. 2019;27:2494-2501. [Crossref]

15. Carpenter JE, Kasman RA, Patel N, Lee ML, Goldstein SA. Biomechanical evaluation of current patella fracture fixation techniques. J Orthop Trauma. 1997;11:351-356. [Crossref]

16. Henrichsen JL, Wilhem SK, Siljander MP, Kalma JJ, Karadsheh MS Treatment of patella fractures. Orthopedics. 2018;41:e747-e755. doi: 10.3928/01477447-20181010-08. [Crossref]

17. Böstman O, Kiviluoto O, Nirhamo J. Comminuted displaced fractures of the patella. Injury. 1981;13:196-202. [Crossref]

18. Smith ST, Cramer KE, Karges DE, Watson JT, Moed BR. Early complications in the operative treatment of patella fractures. J Orthop Trauma. 1997;11:183-187. [Crossref]

19. Sorensen $\mathrm{KH}$. The late prognosis after fracture of the patella. Acta Orthop Scand. 1964;34:198-212. [Crossref]

20. Baydar ML, Atay T, Gürbüz Ö, Baykal BY, Burç H, Kırdemir V, et al. Compressive screwing of transverse patella fractures provides better resistance to traction than tension band. Eur J Orthop Surg Traumatol. 2011;21:105110. [Crossref]

21. Wurm S, Augat $P$, Bühren V. Biomechanical assessment of locked plating for the fixation of patella fractures.J Orthop Trauma. 2015;29:e305-e308. [Crossref]

22. Martin JM, Applin DT, McGrady LM, Wang M, Schmeling GJ. Biomechanical comparison of tension band fixation of patella transverse fracture: headless screws versus headed screws. J Orthop Trauma. 2019;33:e240-e245. [Crossref]

23. Burvant JG, Thomas KA, Alexander R, Harris MB. Evaluation of methods of internal fixation of transverse patella fractures: a biomechanical study. J Orthop Trauma. 1994;8:147-153. [Crossref] 